\title{
Karakteristik Sensori Kopi Celup Dan Kopi Instan Varietas Robusta Dan Arabika
}

\section{Sensory Characteristics Of Coffee Bag and Instant Coffee Of Robusta and Arabika Varieties}

\author{
N. Nurhayati \\ Program Studi Teknologi Hasil Pertanian, Jurusan Teknologi Hasil Pertanian, Fakultas Teknologi \\ Pertanian, Universitas Jember \\ nurhayati.ftp@unej.ac.id
}

\begin{abstract}
Abstrak
Coffee is one of the plantation commodities that contribute to the significant role for agricultural development in Indonesia. Indonesia has two main coffee varieties, namely Arabica coffee and Robusta coffee. The objectives of the study were characterization of physical properties and quality of sensory coffee dye and instant coffee. The materials used are Robusta coffee and Arabica coffee. Physical properties analyzed were total dissolved solids by using refractometer. Sensory quality was tested by a distinctive scoring method that included aroma, taste, viscosity and color parameters. The results showed that the highest total dissolved solids were Arabica dye $(43,67)$ compared to Robusta coffee $(\mathbf{4 2 , 8 0})$. Instant coffee has the strongest flavor, taste and viscosity characteristics compared to coffee dyes. A strong flavor quality is owned by Arabica instant coffee. The strongest steeping quality is owned by Robusta instant coffee. High filling (condensed) is owned by Arabica type instant coffee. The color of the dark sedan is owned by Arabica instant coffee and Robusta.
\end{abstract}

Keywords : Dye Coffee, Instant Coffee, Arabika, Robusta, sensory.

\section{PENDAhuluaN}

Kopi merupakan salah satu hasil komoditi perkebunan yang memiliki nilai ekonomis yang cukup tinggi di antara tanaman perkebunan lainnya dan berperan penting sebagai sumber devisa negara. Kopi tidak hanya berperan penting sebagai sumber devisa melainkan juga merupakan sumber penghasilan bagi tidak kurang dari satu setengah juta jiwa petani kopi di Indonesia. Keberhasilan agribisnis kopi membutuhkan dukungan semua pihak yang terkait dalam proses produksi kopi pengolahan dan pemasaran komoditas kopi. Upaya meningkatkan produktivitas dan mutu kopi terus dilakukan sehingga daya saing kopi di Indonesia dapat bersaing di pasar dunia (Rahardjo, 2012).

Kopi Robusta memiliki kelebihan dari segi karakteristik yaitu tahan terhadap serangan penyakit, memiliki aroma dan rasa paling kuat diantara jenis kopi lainnya. Indonesia termasuk negara salah satu penghasil dan pengekspor kopi Robusta karena kondisi lahan dan iklim Indonesia lebih cocok untuk budidaya kopi Robusta. Ekspor kopi Indonesia sudah dimulai pada jaman penjajahan Belanda untuk memenuhi kebutuhan konsumsi kopi dunia. Kopi Arabika umumnya menjadi kebanggaan tersendiri bagi Indonesia dan khususnya di Bali, karena kopi Arabika Kintamani memiliki kualitas yang baik dan memiliki ciri khas yaitu bercitarasa jeruk (Saputra E, 2008). Kintamani merupakan produsen kopi Arabika terbesar di Bali dan terdaftar sebagai wilayah MPIG (Masyarakat Perlindungan Indikasi Geografi) yang memberikan perlindungan hukum dalam meningkatkan dan mengembangkan sumber daya alam yang dimiliki serta mempermudah perdagangan produk yang dihasilkan baik ke pasar nasional maupun internasional.

Produk kopi yang terdapat di pasaran semakin beragam menyesuaikan perkembangan teknologi dan trend atau pola konsumsi masyarakat. Salah satu produk kopi yang banyak dipasarkan adalah kopi instan siap seduh dengan berbagai varian rasa. Perkembangan produk kopi berupa kopi celup belum banyak dikembangkan. Oleh karena itu penelitian ini melakukan formulasi kopi celup dan kopi instan dari varietas kopi Arabika dan kopi Robusta yang selanjutnya dikarakterisasi sifat fisik dan mutu sensori. 


\section{METODOLOGI}

\section{Alat dan Bahan}

Alat yang digunakan untuk membuat kopi instan dan kopi celup yaitu panci, kompor, teflon, spatula, sendok, mortar, ayakan, dan neraca analitik. Alat yang digunakan untuk analisis mutu fisik dan sensori kopi adalah hand refraktometer, gelas alumunium, dan gelas sloki. Bahan yang digunakan untuk membuat kopi celup dan instan yaitu kopi Arabika, kopi Robusta, air , gula pasir, dan kain saring. Bahan yang digunakan untuk analisis mutu fisik dan sensori kopi adalah kuisioner.

\section{Pembuatan Kopi Instan}

Pembuatan kopi instan menggunakan bahan utama berupa kopi bubuk jenis Arabika dan Robusta. Kopi ditimbang sebanyak 30 gram. Kemudian dilakukan ekstraksi dengan penambahan $450 \mathrm{ml}$ air mendidih. Penggunaan air mendidih dalam ekstraksi berfungsi untuk mempercepat proses pelarutan ingredien kopi. Selanjutnya dilakukan pengadukan agar terbentuk suspensi lalu didiamkan selama 5 menit. Kemudian difiltrasi untuk menghasilkan filtrat dan ampas. Filtrat ditambah gula sebanyak 225 gram, kemudian dipanaskan hingga mengkristal. Selama proses pemanasan dilakukan pengadukan, semakin mendekati kental maka dilakukan pengadukan secara terus menerus agar tidak gosong. Selanjutnya diangkat dari kompor dan dilakukan pengadukan lebih lanjut sambil menunggu terbentuknya padatan kristal kopi instan. Kristal kopi instan didinginkan dan dilakukan pengecilan ukuran menggunakan mortar atau blender kering. Tahap terakhir dilakukan pengayakan agar diperoleh kopi instan bubuk yang halus dan seragam.

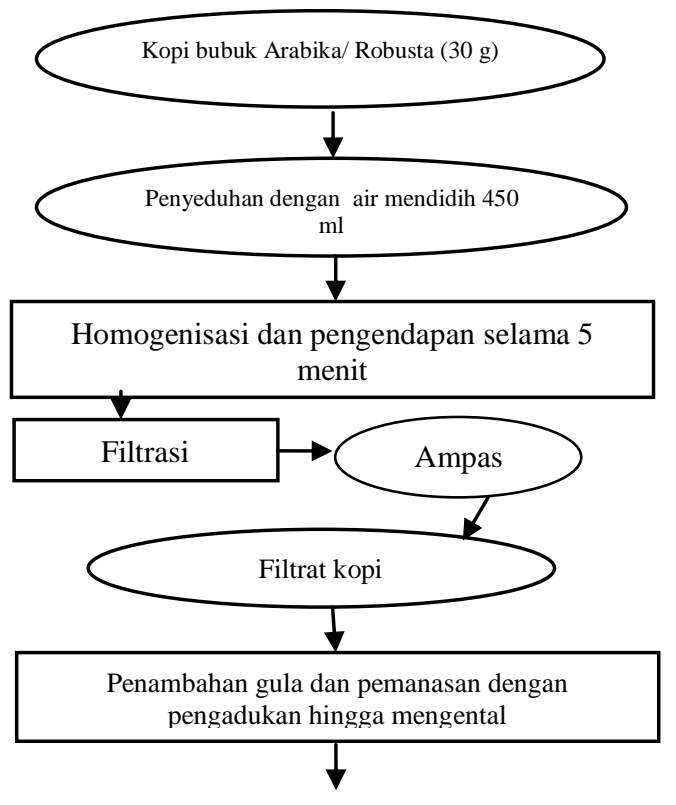

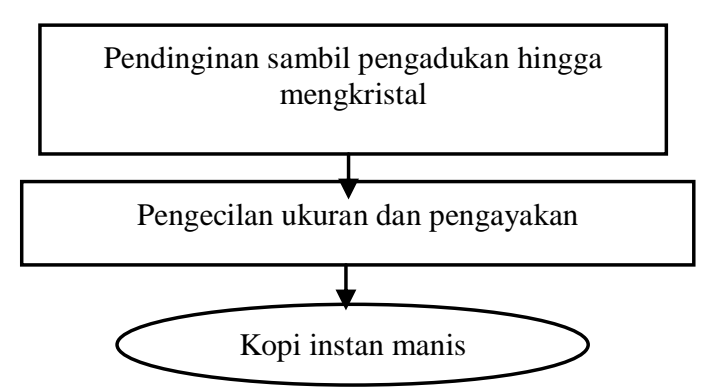

GAMBAR 1. SKEMA PEMBUATAN KOPI INSTAN

\section{Pembuatan Kopi Celup}

Pembuatan kopi celup dilakukan dengan menggunakan pengemas kain saring steril untuk kopi bubuk Arabika dan kopi bubuk Robusta. Kopi bubuk ditimbang sebanyak 30g. Kemudian dimasukan ke dalam kain saring serta diikat menggunakan tali untuk mencegah kopi keluar dari kain saring. Kain saring berfungsi sebagai filter dalam proses ekstraksi kopi (penyeduhan). Selanjutnya kopi celup diseduh selama 5 menit dengan ditambahkan air panas sebanyak $300 \mathrm{ml}$. Penambahan air panas bertujuan untuk melarutkan kopi celup. Seduhan kopi celup kemudian dianalisis mutu fisik dan sensorinya.

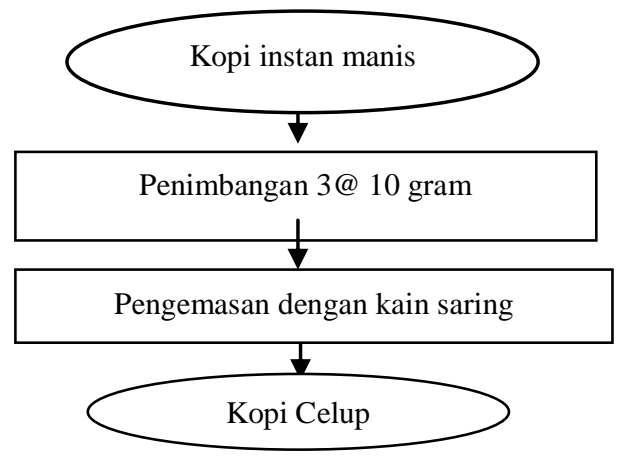

GAMBAR 2. SKEMA PEMBUATAN KOPI CELUP

\section{Pengukuran Total Padatan Terlarut}

Pengamatan total padatan terlarut (derajat Brix) dilakukan menggunakan alat yang disebut refraktometer. (Hidayanto, 2010). Pengukuran padatan terlarut dilakukan dengan meneteskan seduhan kopi pada hand refractometer, lalu angka hasil pengukuran diamati dan dicatat. Pengukuran di ulang sebanyak $3 x$ pengulangan.

\section{Analisis Sensori}

Mutu sensori atau penerimaan konsumen terhadap kopi dilakukan menggunakan metode analisis mutu skoring pembedaan. Analisis mutu skoring merupakan analisis mutu dengan meminta panelis untuk menilai penampilan sampel berdasarkan intensitas atribut atau sifat yang dinilai dengan menggunakan skala angka yang 
dicantumkan dalam kuisoner. Analisis uji skoring jenis sampel yang digunakan adalah kopi dengan kode 741 (Robusta instan), kopi kode 524 (Arabika instan), kopi kode 136 (Robusta celup) dan kopi kode 812 (Arabika celup). Skala angka yang tercantum dalam kuesioner meliputi: rasa dan aroma yaitu 1= sangat lemah, 2= lemah, 3= agak kuat, $4=$ kuat dan $5=$ sangat kuat; tingkat kekentalan yaitu $1=$ sangat encer, $2=$ encer, $3=$ agak kental, $4=$ kental dan $5=$ sangat kental; warna yaitu $1=$ sangat terang, $2=$ terang, 3 agak gelap, $4=$ gelap dan $5=$ sangat gelap.

Uji sensori dilakukan oleh 38 panelis semi terlatih yang secara spontan bersedia menjadi panelis setelah diberi penjelasan singkat terkait dengan penganalisis mutuan. 38 panelis tersebut adalah mahasiswa kelas B mata kuliah Teknologi Pengolahan Komoditi Perkebunan Hilir komoditi kopi yang diambil secara acak. Air putih disediakan agar tidak terjadi bias pada saat melakukan uji sensori antar sampel uji. Selanjutnya data direkap dan dianalisis statistik.

\section{PEMBAHASAN}

\section{Total Padatan Terlarut Seduhan Kopi}

Total padatan terlarut merupakan ukuran zat terlarut dalam air (baik zat organik maupun anorganik). Material-material yang tergolong dapat larut dalam air seperti karbonat, bikarbonat, klorida, sulfat, fosfat, nitrat, kalsium, magnesium, natrium, ion-ion organik, dan ion-ion lainnya. Kualitas rasa manis suatu bahan pangan dapat diukur dengan pengukuran total padatan terlarut karena gula merupakan komponen utama dari padatan terlarut. Kandungan total padatan terlarut meliputi zat terlarut (zat organik maupun zat anorganik) misalnya gula, asam dan garam, sehingga semakin tinggi penambahan larutan garam maka akan semakin tinggi nilai total padatan terlarut yang terbaca (Pamungkas, 2016). Tabel 1 menyajikan total padatan terlarut seduhan kopi celup dan kopi instan untuk jenis kopi Robusta dan Arabika.

Tabel 1. Total Padatan Terlarut Seduhan Kopi CELUP DAN KoPI INSTAN JENIS RobUSTA DAN ARABIKA

\begin{tabular}{cc}
\hline Sampel & Skor \\
\hline Kopi Robusta & $42,8 \pm$ \\
Celup & 0,2 \\
Kopi Robusta & $37,03 \pm$ \\
Instan & 0,06 \\
Kopi Arabika & $43,67 \pm$ \\
Celup & 0,15 \\
Kopi Arabika & $33,37 \pm$ \\
Instan & 0,15 \\
\hline
\end{tabular}

Total padatan terlarut diperoleh nilai derajat brix paling tinggi pada kopi Arabika celup yaitu $43.67 \pm 0.15$, dikuti kopi Robusta celup $42.08 \pm 0.2$, kopi Robusta instan $37.03 \pm 0.06$ dan terendah pada kopi Arabika instan $33.37 \pm 0.15$. Padatan terlarut kopi intan dari jenis Robusta lebih tinggi daripada kopi instan jenis Arabika. Hal ini dapat terjadi karena padatan kopi Robusta yang terekstrak pada proses ekstraksi lebih banyak daripada padatan yang terekstrak dari kopi Arabika. Pernyataan ini sesuai dengan pernyataan Capek et al. (2014) dalam Tarigan et al. (2015) yang menyatakan bahwa kopi instan yang beredar di pasaran Indonesia merupakan jenis Robusta, mempunyai rendemen hasil ekstraksi yang tinggi, sementara kopi Arabika biasanya digunakan untuk memperbaiki citarasa dan aroma.

Spillane (1990) dalam Oktadina et al. (2013) menjelaskan bahwa kopi jenis Arabika lebih banyak mengandung zat gula dan minyak atsiri sehingga pada saat ekstraksi dengan air panas zat gula yang terekstrak lebih banyak yang menyebabkan derajat Brix lebih tinggi dan terukur sebagai padatan terlarutnya lebih banyak.

Dalam pembuatan kopi instan terdapat proses kristalisasi ulang dengan proses pemanasan yang lama dan dengan suhu tinggi, sedangkan pada pembuatan kopi celup tidak mengalami pemanasan. Proses pemanasan dapat menyebabkan sukrosa terdegradasi menjadi frukstosa dan glukosa. Hal ini dapat menyebabkan nilai derajat Brix nira kopi instan lebih rendah daripada derajat Brix kopi celup yang hanya mengalami penyeduhan saja. Pernyataan tersebut sesuai dengan pernyataan Wang (2004) dalam Jaya et al. (2016) bahwa sukrosa akan mengalami degradasi akibat lingkungan yang asam, panas, dan mineral tertentu melalui reaksi hidrolisis.

\section{Aroma Seduhan Kopi}

Aroma mempengaruhi citarasa dan tingkat favorit dari para panelis. Aroma bubuk kopi instan timbul karena adanya senyawa-senyawa yang mudah menguap. Dalam pembuatan kopi instan senyawa mudah menguap tersebut dilarutkan dalam air panas agar ikut terekstrak dan membentuk aroma kopi instan yang dihasilkan (Bhumiratana et al. 2011). Mutu sensori aroma seduhan Kopi Robusta dan Arabika disajikan pada Tabel 2.

Tabel 2. Mutu Sensori Aroma Seduhan Kopi Celup DAN KOPI INSTAN JENIS ROBUSTA DAN ARABIKA

\begin{tabular}{ccl}
\hline Sampel & Skor & $\begin{array}{c}\text { Deskripsi } \\
\text { Mutu }\end{array}$ \\
\hline Kopi & $2,37 \pm$ & Lemah \\
Robusta & 0,88 & \\
Celup & & Agak kuat \\
Kopi & $3,61 \pm$ & \\
Robusta & 0,68 & \\
Instan & & Lemah \\
Kopi & $2,34 \pm$ & \\
Arabika & 0,63 & \\
Celup & & Mendekati \\
Kopi & $3,89 \pm$ & kuat \\
Arabika & 0,86 & \\
Instan & &
\end{tabular}


Tabel 2 menunjukkan rata-rata mutu aroma seduhan kopi celup adalah lemah sedangkan kopi instan adalah kuat. Mutu kopi celup adalah 2,37 (lemah) untuk jenis Robusta dan 2,34 (lemah) untuk jenis Arabika. Mutu kopi instan adalah 3,61 (agak kuat) untuk jenis Robusta dan 3,89 (mendekati kuat) untuk jenis Arabika. Berdasarkan data tersebut baik pada kopi Robusta maupun kopi Arabika, aroma yang paling kuat dimiliki oleh kopi dengan pengolahan instan. Hal ini dikarenakan pada pengolahan kopi instan seluruh komponen kopi diseduh tanpa menghasilkan ampas sehingga seluruh komponen volatil yang terdapat pada kopi tidak ada yang terbuang dan membuat aroma kopi instan lebih kuat dibandingkan dengan kopi celup yang diseduh dengan menyisakan ampas kopi.

Menurut Baggenstoss et al. (2008), terbentuknya aroma yang khas pada kopi disebabkan oleh kafeol dan senyawa-senyawa komponen pembentuk aroma kopi lainnya. Asamasam organik yang terdapat dalam kopi merupakan komponen yang membentuk aroma kopi saat diseduh. Sebagian senyawa pembentuk aroma merupakan senyawa yang mudah menguap yang rentan terhadap panas yang terlalu tinggi. Semakin banyak senyawa mudah menguap yang larut dalam air ketika penyeduhan semakin tajam aroma yang dihasilkan.

\section{Rasa Seduhan Kopi}

Rasa merupakan salah satu faktor utama yang menentukan tingkat penerimaan konsumen terhadap suatu produk pangan. Selera konsumen juga merupakan faktor yang menentukan diterima tidaknya rasa produk pangan yang ditawarkan. Dalam penelitian ini dilakukan analisis mutu rasa menggunakan metode analisis mutu pembedaan skoring kopi Robusta instan dan celup, serta kopi Arabika celup dan instan.

TABEL 3. MUTU SENSORI RASA SEDUHAN KOPI CELUP DAN KOPI INSTAN JENIS ROBUSTA DAN ARABIKA

\begin{tabular}{ccc}
\hline Sampel & Skor & Deskripsi Mutu \\
\hline Kopi & $2,79 \pm$ & Mendekati \\
Robusta & 0,93 & agak kuat \\
Celup & & \\
Kopi & $3,84 \pm$ & Kuat \\
Robusta & 1,00 & \\
Instan & & \\
Kopi & $2,74 \pm$ & Mendekati \\
Arabika & 0,89 & agak kuat \\
Celup & & \\
Kopi & $3,63 \pm$ & Mendekati \\
Arabika & 0,71 & kuat \\
Instan & & \\
\hline
\end{tabular}

Tabel 3 menunjukkan mutu rasa kopi Robusta celup adalah 2,79; kopi Robusta instan 3,84; kopi Arabika celup 2,74; dan kopi Arabika instan 3,63. Kopi Robusta instan memiliki mutu sensori rasa lebih tinggi dibandingkan kopi Robusta celup, begitu pula pada hasil analisis mutu kopi Arabika. Hal ini dikarenakan rasa pada kopi instan jenis Robusta maupun Arabika lebih kuat. Kopi Robusta instan dalam penyajiannya semua kopi diseduh tanpa menghasilkan residu, sedangkan pada kopi Robusta celup hanya diambil ekstraknya saja dan dipisahkan ampasnya. Terseduhnya seluruh kopi (tanpa ampas) pada kopi instan akan menghasilkan rasa kopi yang lebih kuat daripada kopi celup yang menyisakan ampas.

Menurut Rahardjo (2012), kopi Robusta memiliki ciri rasa asam yang khas, bahkan tidak ada rasa asam sama sekali, memiliki aroma yang manis, rasanya lembut (mild), kadar kafeinnya dua kali lebih banyak daripada kopi Arabika. Kopi Instan merupakan seduhan kopi bubuk yang dipanaskan bersama gula hingga membentuk serbuk kopi siap seduh. Dalam pemrosesannya, kopi instan diberi tambahan gula sedangkan kopi celup hanya menggunakan bubuk kopi saja dan baru diberi tambahan gula ketika hendak diseduh.

Menurut AEKI (2006) Kopi Arabika dianggap lebih baik daripada Robusta karena rasanya lebih enak dan jumlah kafeinnya lebih rendah. Menurut Mahardika (2011), pada dasarnya kopi celup sama seperti teh celup. Kopi celup diperoleh dari biji kopi yang telah dihancurkan kemudian dimasukkan ke dalam suatu kemasan yang berbentuk seperti filter (saringan). Dengan adanya kopi celup maka ampas yang biasanya dihasilkan pada waktu kopi diseduh dengan air panas akan berkurang atau bahkan tidak ada sama sekali karena kopi celup merupakan kelanjutan dari proses pembuatan kopi instan.

\section{Kekentalan Seduhan Kopi}

Menurut Setyaningsih (2010), analisis mutu sensori sangat berperan penting dalam pengembangan produk dan mengurangi resiko pengambil keputusan. Dalam analisis mutu sensori panelis dapat mengidentifikasi atribut-atribut produk untuk mendeskripsikan produk tersebut. Analisis mutu sensori juga dapat digunakan untuk mendapatkan nilai yang membuat adanya perubahan yang diinginkan atau tidak diinginkan dalam produk atau bahan formulasi, mengidentifikasi produk untuk pengembangan, menentukan nilai optimal dari produk tersebut. Penilaian hasil analisis mutu organoleptik dari segi kekentalan pada kopi ini bertujuan untuk menganalisis preferensi konsumen terhadap atribut kopi bubuk dan kopi instan, bagaimana korelasi antara atribut-atribut kopi bubuk dan kopi instan. 
Tabel 4. Mutu Sensori KeKentalan Seduhan Kopi CELUP DAN KoPI INSTAN JENIS RobUSTA DAN ARABIKA

\begin{tabular}{ccl}
\hline Sampel & Skor & $\begin{array}{c}\text { Deskripsi } \\
\text { Mutu }\end{array}$ \\
\hline Kopi & 2,37 & Encer \\
Robusta & \pm & \\
Celup & 0,61 & \\
Kopi & 3,61 & Mendekati \\
Robusta & \pm & kental \\
Instan & 0,68 & \\
Kopi & 2,74 & Mendekati \\
Arabika & \pm & agak kental \\
Celup & 0,89 & \\
Kopi & 3,63 & Mendekati \\
Arabika & \pm & kental \\
Instan & 0,71 & \\
\hline
\end{tabular}

Tabel 4 menunjukkan mutu sensori tingkat kekentalan kopi Robusta celup sebesar 2,37, kopi Robusta instan sebesar 3,61, kopi Arabika celup sebesar 2,74, dan kopi Arabika instan 3,63. Tingkat kekentalan kopi instan lebih kental daripada kopi Robusta celup baik untuk kopi jenis Robusta maupun jenis Arabika. Hal ini dikarenakan pada pengolahan instan seluruh kopi diseduh tanpa menghasilkan residu (ampas), sedangkan pada pengolahan celup menghasilkan residu (ampas) sehingga hasil seduhan akan lebih encer. Kekentalan atau viskositas pada kopi mendeskripsikan kandungan protein dan serat yang terlarut pada kopi. Semakin kental kopi tersebut, konsumen akan menyukai kopi tersebut karena hal ini akan mempengaruhi cita rasa yang kuat pada kopi tersebut (Panggabean, 2011).

\section{Warna Seduhan Kopi}

Salah satu parameter kualitas dari hasil seduhan kopi ialah warna. Indera pengelihatan merupakan sensor paling awal untuk mengetahui mengukur kualitas warna dari kopi tersebut. Mutu sensori warna kopi celup dan kopi instan jenis Robusta dan Arabika disajikan pada Tabel 5.

TABel 5. Mutu SENSORI WARNA KoPI CELUP DAN KoPI INSTAN JENIS ROBUSTA DAN ARABIKA

\begin{tabular}{ccl}
\hline Sampel & Skor & $\begin{array}{c}\text { Deskripsi } \\
\text { Mutu }\end{array}$ \\
\hline Kopi & 2,58 & Mendekati \\
Robusta & \pm & agak gelap \\
Celup & 0,86 & \\
Kopi & 4,26 & Gelap \\
Robusta & \pm & \\
Instan & 0,86 & \\
Kopi & 2,34 & Terang \\
Arabika & \pm & \\
Celup & 0,63 & \\
Kopi & 4,13 & Gelap \\
Arabika & \pm & \\
Instan & 0,78 & \\
\hline
\end{tabular}

Mutu sensori warna seduhan tertinggi ialah seduhan kopi Robusta instan $(4,26 \pm 0,86)$, diikuti seduhan kopi Arabika instan (4,13 \pm 0,78), seduhan kopi Robusta celup $(2,58 \pm 0,86)$ dan seduhan kopi Arabika celup $(2,34 \pm 0,63)$. Skor mutu warna tertinggi adalah seduhan kopi Robusta instan $(4,26 \pm 0,86)$. Hal ini menunjukkan bahwa warna seduhan kopi instan lebih gelap daripada kopi celup (Gambar 3).

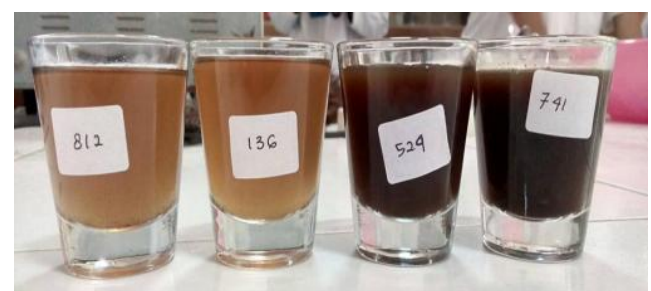

GAMBAR 3. WARna SEDUHAN Kopi CELUP DAN INSTAN

JENIS KOPI ARABIKA DAN ROBUSTA: 741 (ROBUSTA INSTAN), 524 (ARABIKA INSTAN), 136 (ROBUSTA CELUP) DAN 812 (ARABIKA CELUP)

Proses penyangraian yang dilakukan pada biji kopi Robusta maupun kopi Arabika dapat mempengaruhi warna bubuk kopiyang dihasilkan. Selama proses penyangraian terjadi perubahanperubahan warna yang dapat dibedakan secara visual. Menurut Bunde et al (2010) bubuk kopi Robusta instan yang berwarna cokelat akan berwarna hitam ketika diseduh. Menurut Penggabean (2011), di dalam kopi terkandung protein, dan protein dari kopi Robusta cenderung lebih tinggi. Adanya gula-gula preduksi, gugus amina dari protein dan kadaan suhu tinggi mendukung terjadinya reaksi maillard. Reaksi maillard ini menghasilkan perubahan bahan menjadi coklat dan lebih gelap. Sementara itu pada proses pembuatan kopi celup ialah ekstraksi bubuk kopi dengan air panas. Jika dibandingkan antara kopi celup dan instan yang memiliki warna paling gelap yaitu kopi instan. Hal ini dapat disebabkan karena pada proses pembuatan kopi instan melalui proses karamelisasi yang menyebabkan kandungan gula berubah akibat pemanasan dan pada kopi celup tidak mengalami karamelisasi sehingga warna yang dihasilkan kurang kuat. Suhu yang tinggi mampu mengeluarkan sebuah molekul air dari setiap molekul gula sehingga terjadilah glukosan, suatu molekul yang analog dengan fruktosan. Proses pemecahan dan dehidrasi diikuti dengan polimerisasi yang menghasilkan warna kecoklatan (Arsa, 2016).

\section{KESIMPULAN}

Karakteristik kopi celup dan kopi instan berbeda baik kopi jenis Arabika maupun Robusta. Karakteristik fisik berupa total padatan terlarut seduhan kopi celup lebih tinggi daripada kopi 
instan baik total padatan. Akan tetapi karakteristik mutu sensori seduhan kopi celup lebih rendah daripada kopi instan baik untuk mutu sensori rasa, aroma, kekentalan maupun warna. Mutu aroma yang kuat dimiliki oleh kopi instan jenis Arabika. Mutu rasa seduhan yang paling kuat dimiliki oleh kopi instan jenis Robusta. Kentalan yang tinggi (kental) dimiliki oleh kopi instan jenis Arabika. Warna seduhan yang gelap dimiliki oleh kopi instan jenis Arabika maupun Robusta.

\section{UCAPAN TERIMA KASIH}

Penulis mengucapkan terima kasih kepada mahasiswa pelaksana praktikum topik kopi celup dan instan yaitu: Andry Setiya P, Akbar Bayu E, Herinda Putri S, Fatmawati W, Yayan Priyo H, Muja Mufida, Zela O, Susi Maimona, Wilda Mukholida, Yulinda Angesti, Emilia W, Dimas Septian, Irna N, Agnes Emilda, Melly Putri, Feri Zainul. Terima kasih juga penulis sampaikan kepada Universitas Jember atas dana yang diberikan melalui dana BOPTN Tahun Ajaran 2016/2017 Semester Genap.

\section{DAFTAR PUSTAKA}

[1] AEKI (Asosiasi Eksportir Kopi Indonesia). 2006. Statistik Kopi 2003-2005. Jakarta.

[2] Arsa, M. 2016. Proses Pencoklatan (Browning Process) pada Bahan Pangan. Bali : Universitas Udayana.

[3] Baggenstoss, J., L. Poisson, A., Glabasnia, M., Moser, A., Rytz, E., Thomas, I. Blank \& J. Kerler. 2010. Advanced analytical-sensory correlationtowards a better understanding of coffee flavor perception. Proceedings 23rd International Conference on Coffee Science $3 \mathrm{rd}-8$ th October 2010. p. 125-132. Bali, Indonesia.

[4] Bhumiratana, N., K. Andhikari, and E. Chamber. 2011. Evolution of sensory aroma attributes from coffee beans to brewed coffee. LWT Food Science and Technology 44: 2185-2192

[5] Bunde, M.C.,Osundahunsi, F.O., Akinoso, R. 2010. Suplementation of Biscuit using rice bran and soybean flour. African Journal of Food Agriculture, Nutrition and Development 10:9, 4047-4059.

[6] Hidayanto, E. 2010. Aplikasi Portable Brix Meter untuk Pengukuran Indeks Bias. Jurnal Berkala Fisika. Vol. 13. No. 4. Semarang.

[7] Jaya, R. S., Ginting, S. dan Ridwansyah. 2016. Pengaruh Suhu Pemanasan dan Lama Penyimpanan Terhadap Perubahan Kualitas Nira Aren (Arenga pinnata). Jurnal Rekayasa Pangan dan Pertanian. Vol. 4 (1).

[8] Mahardika, E.T. 2011. Peluang Bisnis Kopi Celup. Jurusan Teknik Informatika Sekolah Tinggi Manajemen Informatika dan Komputer.
Yogyakarta : AMIKOM.

[9] Oktadina, F. D., Argo, B. W., dan Hermawanto, M.B. 2013. Pemanfaatan Nanas (Ananasconosus L. Merr) untuk Penurunan Kadar Kafein dan Perbaikan Citarasa Kopi (Coffe sp.) dalam Pembuatan Kopi Bubuk. .Jurnal Keteknikan Pertanian Tropis dan Biosistem. Vol. 1 (3): 265273.

[10] Pamungkas, B. T. 2016. "Pembuatan Nira Kelapa Fermentasi dengan Metode Moromi untuk Pensubstitusi Kecap Asin”. Skripsi. Bogor: Institut Pertanian Bogor.

[11] Panggabean, E. 2011. Buku Pintar Kopi. Jakarta : PT Agro Media Pustaka.

[12] Rahardjo. 2012. Kopi Panduan Budidaya dan Pengolahan Kopi Arabika dan Robusta. Jakarta: Penebar Swadaya.

[13] Saputra, E. 2008. Kopi. Yogyakarta : Harmoni.

[14] Setyaningsih, D., Anton, A., dan Sari, M.P. 2010. Analisis Sensori untuk Industri Pangan dan Agro. Bogor : IPB Press.

[15] Tarigan, E.B., Pranowo, D., dan Iflah, T. 2015. Level of Consumers Preferences on Coffe Blend of Robusta and Arabica .Jurnal Teknologi dan Industri Pertanian Indonesia.Vol. 7 (1). 